\title{
Evolutionary reduction of female dispersal in Cataglyphis desert ants
}

\author{
CHRISTIAN PEETERS ${ }^{1 *}$ and SERGE ARON ${ }^{2}$ \\ ${ }^{1}$ Institute of Ecology and Environmental Sciences, UMR CNRS 7618, Sorbonne Universités UPMC, Paris \\ 75005, France \\ ${ }^{2}$ Evolutionary Biology and Ecology, CP 160/12, Université Libre de Bruxelles, Brussels 1050, Belgium
}

Received 22 March 2017; revised 26 April 2017; accepted for publication 26 April 2017

\begin{abstract}
Sexual activity is only a brief moment in the life of ant colonies, but it determines several characteristics of life history. Mating behaviour, distance of female dispersal and mode of colony foundation are interlinked. In species exhibiting 'male aggregation' (males and queens fly and mate away from natal nests), newly mated queens have no option but to found a colony alone (independent colony founding, ICF). In contrast, in 'female calling' species, queens mate close to the natal nests, then either fly or walk away for dispersal. In several species, they can also disperse on foot accompanied by nestmate workers (dependent colony founding, DCF). Here, we review field observations and genetic data to untangle dispersal strategies across the genus Cataglyphis. We complement these existing informations with queen thorax morphology and dissection of wing muscles. Our comparative study includes 18 species belonging to six species-groups. We found that female calling occurs across all clades, with only two species showing male aggregation. Although most species have normal flying queens specialized for ICF, species in three out of the six species-groups show DCF. Remarkably, species with DCF evolved short-winged 'brachypterous' queens that lack wing muscles. Relative size of their thorax sclerites can be used to predict lack of flight ability. Altogether, these results show a marked deviation from the breeding behaviour typical of most species in subfamily Formicinae. We discuss how reduction of female dispersal may be linked to harsh desert conditions.
\end{abstract}

ADDITIONAL KEYWORDS: Brachyptery - colony foundation - flight - functional morphology - mating - wing muscles.

\section{INTRODUCTION}

Dispersal is a key life-history trait that determines the distribution and abundance of organisms, their response to changes in the environment, their potential to invade new habitats, and the level of gene flow within and between populations (Clobert et al., 2002). In insects, flight ability is a powerful adaptation enhancing dispersal, along with predator avoidance and food gathering. In social Hymenoptera (all ants, a minority of bees and wasps), only a small proportion of female adults in each colony (queens) participate in dispersal and reproduction, whereas workers carry out all infertile tasks (Wilson, 1971; Bourke \& Franks, 1995). Queens mate at the beginning of adult life; they store a lifetime supply of sperm in a storage organ

*Corresponding author. E-mail: christian.peeters@upmc.fr (spermatheca) and never re-mate. Males die shortly after copulation.

Unlike social bees and wasps, ants are remarkable for evolving a caste of wingless workers. This has important consequences on queen behaviour since it impacts strategies of dispersal and colony foundation. Flight is reduced to a brief period when sexuals are young. In many species, both queens and males fly to a meeting spot away from natal nests ('male aggregation'). After mating, queens disperse further until they have selected a nesting site, and they found a new colony alone (independent colony founding or ' $I C F$ '). In all other species, queens do not fly before mating but stay close to their natal nests, and wait for foreign males ('female calling'). Once mated, such queens have three options according to species: (1) they disperse immediately, usually by flight but also on foot, and found their colony by ICF; (2) they re-enter the natal nests and disperse later on foot together with nestmate workers, 
leading to division of the colony (dependent colony founding or 'DCF'); (3) they re-enter and reproduce in the natal nests (reviewed in Bourke \& Franks, 1995; Peeters \& Molet, 2010; Cronin et al., 2013).

Differences in dispersal strategies typically result in contrasting levels of population viscosity. When queens leave their natal nests on foot, with or without nestmate workers, dispersal is highly restricted in space from less than a meter to a few tens of meters; this results in patterns of 'isolation by distance' (IBD) at small geographical scales, that is, genetic differentiation between colonies increases with geographical distance (Rousset, 2000). Conversely, dispersal by flight results in queens founding colonies further away and there is no IBD at a local scale. Molecular analyses of population viscosity in the field indicate the dispersal abilities of reproductive individuals, but the underlying proximate mechanisms of dispersal often remain poorly understood.

Field observations of mating, dispersal and founding behaviours are impeded by the highly seasonal and short time window of sexual activity. Given that ant queens are morphologically specialized for dispersal and colony foundation, thorax morphology can give precious information about their behaviour (Keller, Peeters \& Beldade, 2014). In ICF species, founding queens are alone during several weeks while they raise the first generation of workers. This solitary phase is risky, but queens in the majority of species have large metabolic reserves that allow to feed the first workers without foraging outside ('claustral' ICF). Other ants exhibit 'non-claustral' ICF, where founding queens must regularly take risks outside the nest to forage for the first larvae. This worker-like behaviour of founding queens requires worker-like neck muscles, housed in the prothorax (first thoracic segment) (Keller et al., 2014). In striking contrast with ICF, DCF is associated with the evolution of short-winged ('brachypterous') or permanently wingless ('ergatoid') queens (Peeters, 2012) in many ant lineages. Flying Hymenoptera have large wing muscles that correspond to an expanded mesothorax (second segment) (Snodgrass, 1956). As a result of losing wing muscles, flightless queens (brachypterous and ergatoid) have a reduced mesothorax and a larger prothorax (Peeters, Keller \& Johnson, 2012).

Cataglyphis desert ants offer an unparalleled opportunity to examine the evolution of dispersal strategies in social Hymenoptera. About 91 species inhabit Old World deserts and arid lands, showing highly similar ecologies (i.e. solitary scavenging for dead arthropods) and colony sizes (several hundreds or few thousands workers). Nonetheless, the genus is characterized by highly varied breeding systems (colonies have single or multiple reproductive queens, and these can be singly- or multiply-mated) and population genetic structures (IBD or not) (reviewed in Lenoir et al., 2009; Aron et al., 2013; Boulay et al., 2017). Out of nine species-groups based on morphological traits (Agosti, 1990; Radchenko, 2001), six have been confirmed to be monophyletic (Knaden et al., 2012; Aron, Mardulyn \& Leniaud, 2016b), opening the way for comparative study of mating and dispersal strategies.

We compiled field observations of young queens in 18 Cataglyphis species belonging to six species-groups. We combined these with population viscosity data and a functional evaluation of queen thorax morphology to show that queens lack a pre-mating flight in most species across all species-groups, and that mating close to natal nests allowed for novel options during dispersal and founding. Given that queen foundation has not been observed in most ant species, our integrative approach can help elucidate this crucial part of the life history of colonies.

\section{METHODS}

\section{SPECIES SAMPLING}

Eighteen species of Cataglyphis belonging to six species-groups (Table 1) were considered. Inclusion criteria were at least two out of three kinds of data about dispersal strategy: (1) field observations of mating behaviour, dispersal and mode of colony foundation; (2) genetic data that allow determination of population viscosity (IBD or not), reflecting queen dispersal over short (a few tens of metres) or long distances, respectively; (3) thorax morphology of queens (ability to fly or not).

Separate studies in widely different localities for C. savignyi (Dufour, 1862) and C. nigra (André, 1881) (often called $C$. niger) described divergent mating and dispersal strategies. This suggests either population-level variations in mating and modes of colony foundation, or different species with distinct behaviours. Indeed, species delimitation in Cataglyphis still needs clarification, because several species are not monophyletic and/or cryptic (Knaden et al., 2012; Aron et al., 2016b). This is especially the case for C. savignyi and $C$. nigra, belonging to the bicolor group.

\section{MATING AND DISPERSAL BEHAVIOUR}

Field observations were used to distinguish between 'male aggregation' (also called 'mating swarm') where males and queens from all colonies in a population fly to meet and mate away from natal nests, and 'female calling' where queens mate close to natal nests before dispersing (by flight or on foot). Because these two conventional mating syndromes are equivocal about female dispersal distance (Peeters \& Molet, 2010), we 


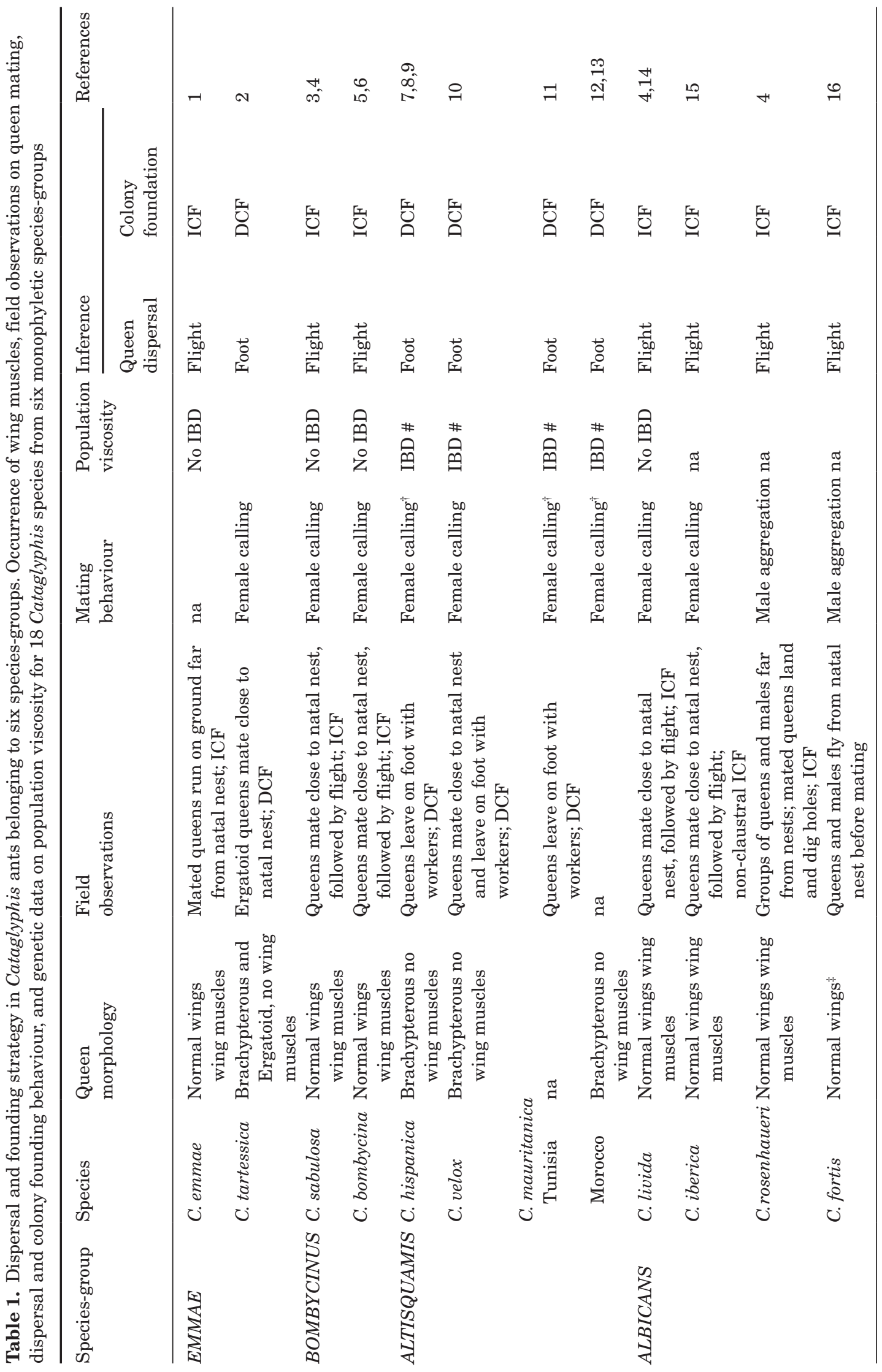




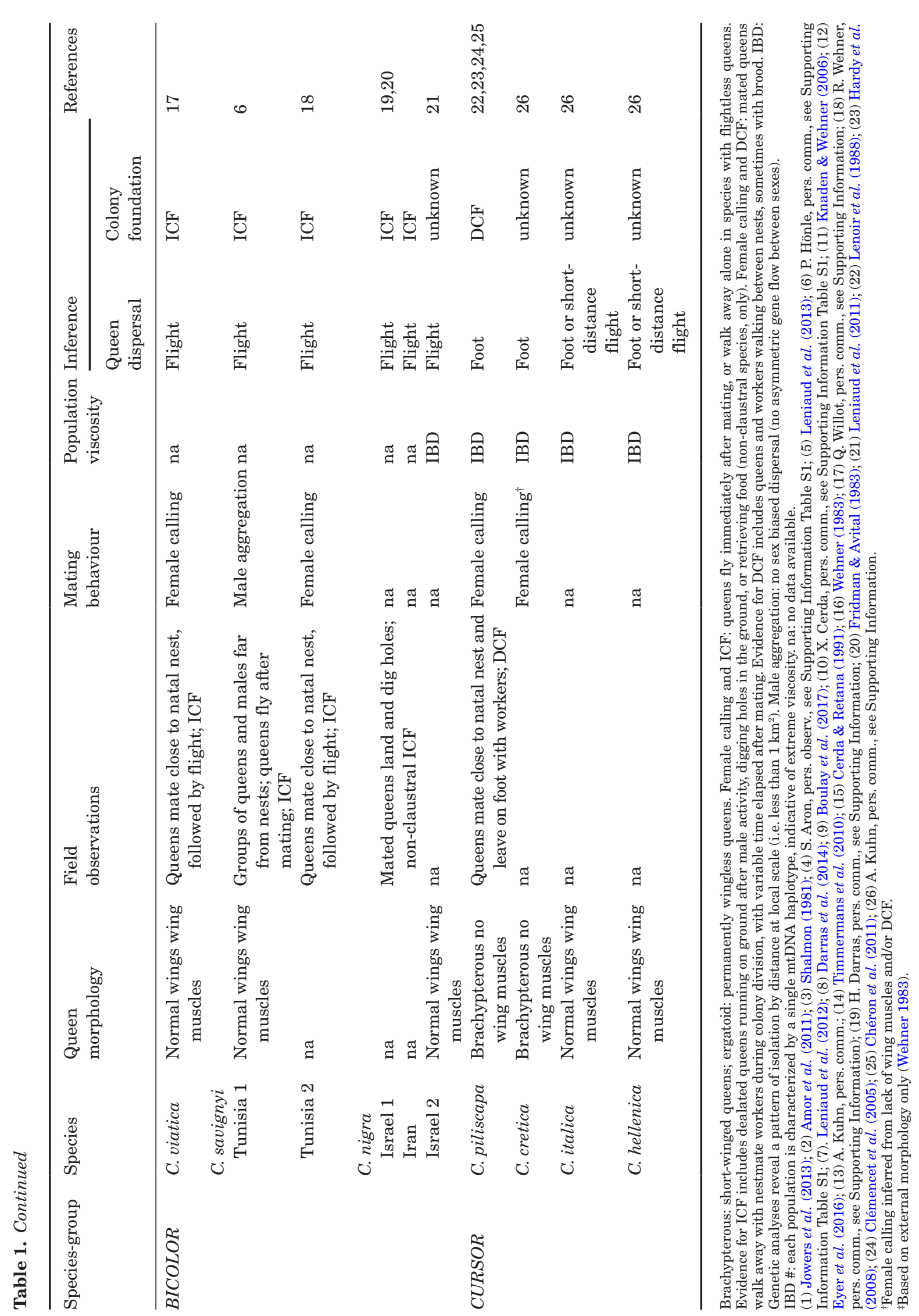


distinguished between events that follow female calling: (1) individual dispersal: mated queens fly away, or in species with flightless queens they walk away alone; (2) colony fission: mated queens re-enter natal nests and later disperse on foot together with nestmate workers (i.e. DCF). We avoided the vague and ambiguous term 'nuptial flight' because it does not differentiate between synchronized exits of males and queens, and exits of single queens (these cannot fly in some species, see below).

\section{MODE OF COLONY FOUNDATION}

In addition to our own field studies, we requested unpublished information from several Cataglyphis researchers (Supporting Information, Table S1). We distinguished between ICF and DCF using field observations and/or inferences from population genetic data (see below). DCF and simple nest emigrations can be separated using the criteria of Cronin et al. (2013). In instances where we collected dealate queens walking above ground, we dissected their spermathecae to check mating status. We differentiated between claustral ICF and non-claustral ICF when field observations were available.

Population genetic data estimated from microsatellite and/or mitochondrial DNA markers were available for eleven species. The occurrence of either ICF or DCF was inferred by comparing genetic differentiation between pairs of colonies within populations, and geographical distance at a small geographical scale, often less than $1 \mathrm{~km}^{2}$ (Slatkin, 1993; Rousset, 2000). A significant Mantel test indicates a pattern of isolation by distance. Such pattern is typically observed in species where young mated queens (1) fly over short distances, (2) cannot fly (i.e. brachypterous and ergatoid queens) and walk alone to found a new colony (ICF), (3) cannot fly and disperse with nestmate workers (DCF) (Ross, 2001; Sundström, Seppä \& Pamilo, 2005; Vitikainen, Haag-Liautard \& Sundström, 2015). Only field observations can distinguish between these options. Field studies on different Cataglyphis species showed that with DCF, new colonies disperse from 1 to about 30 meters away from the natal nests (Boulay et al., 2017).

\section{FUNCTIONAL MORPHOLOGY OF THORAX}

In flying insects, almost all the thorax is filled with the indirect wing muscles (both longitudinal and dorsoventral). Details of the dorsal exoskeleton give reliable information about the existence of these wing muscles (Keller et al., 2014). Most ant queens have huge longitudinal wing muscles, and this is reflected by the large size of the dorsal plate ('mesonotum') of the second segment ('mesothorax' or T2) (Fig. 1a). The longitudinal muscles are attached to two cuticular extensions of T2
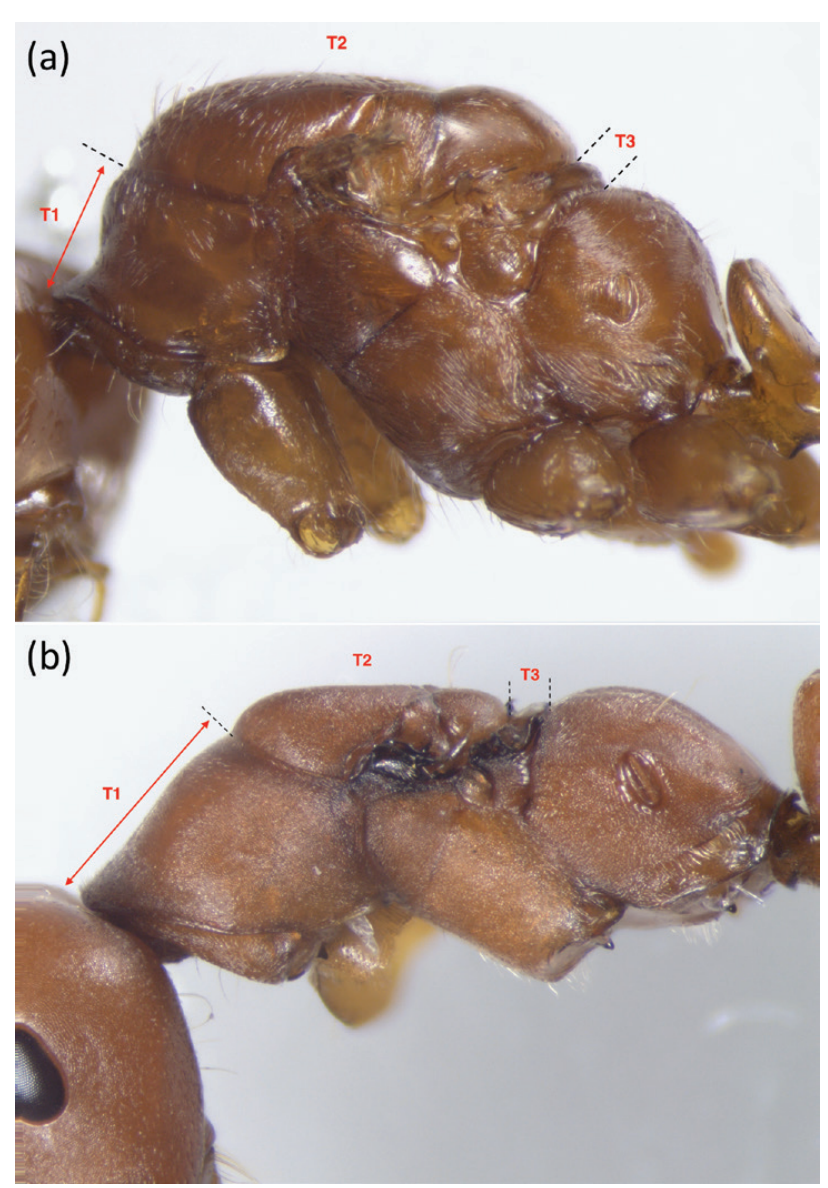

Figure 1. External morphology of queen thorax in Cataglyphis (a) flying (C. bombycina) and (b) non-flying (C. velox). The relative sizes of pronotum (dorsal plate of $\mathrm{T} 1$ ) and mesonotum (T2) vary together with the presence or absence of wing muscles. The metanotum (T3) is reduced in all flying Hymenoptera.

('phragmata', singular 'phragma') having free ends ventrally, allowing muscles to occupy the adjacent segments of thorax (Fig. 2). The first segment ('prothorax' or T1) is small and this restricts the space available for muscles that move the head ('neck muscles') (Keller et al., 2014).

Queens of all species in Table 1 were examined for the existence of wing muscles. Using specimens preserved in ethanol, the thorax was dissected with a fresh razor blade. Wing muscles consist of individual fibres that are much thicker and thus completely distinct from other skeletal muscles (Snodgrass, 1956). Newly mated ant queens soon histolyze their wing muscles to feed the first offspring larvae, so we dissected young virgin queens (i.e. before dealation) where available. In specimens where wing muscles had started to histolyze, we checked for occurrence of the posterior phragma (Peeters et al., 2012). In several species of Cataglyphis, queens have non-functional 

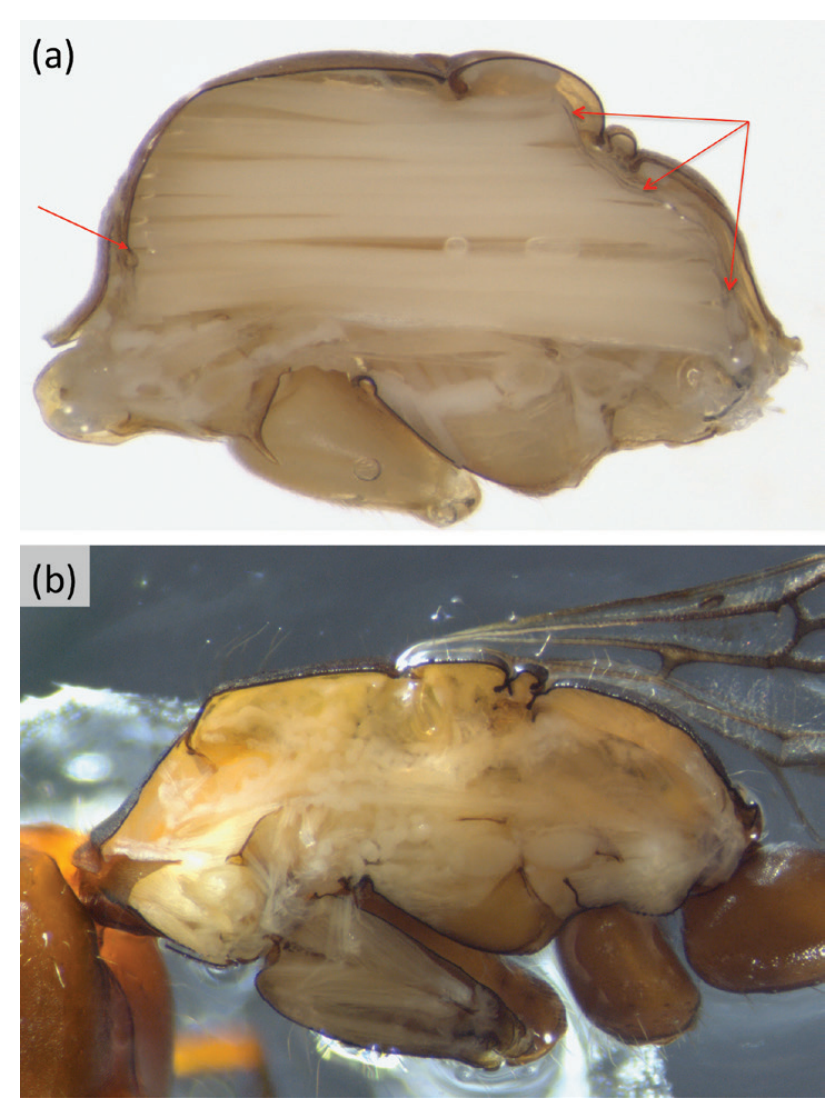

Figure 2. Presence or absence of wing muscles inside Cataglyphis queen thorax. Thick parallel muscle fibres (only longitudinal seen in this plane) are present in (a) young queen of C. emmae, but completely absent in (b) brachypterous queen of $C$. hispanica. Phragmata are indicated with arrows (posterior phragma absent in C. hispanica).

short wings, however many specimens had already shed their wings. Accordingly we examined the size of thorax segments and correlated this with flight ability (wing muscles or not). To characterize thorax segmentation (relative sizes of the prothorax (T1) and mesothorax (T2)), we created dorsal and lateral stacked images of pinned or alcohol specimens. Thorax images of queens from all species studied (Table 1) are deposited on AntWeb.org. Dissections of wing muscles are shown in Fig. 2 and Supporting Information, Figure S1.

\section{RESULTS}

Mature colonies of Cataglyphis are relatively small, usually a few hundreds of workers, but they can reach a few thousands of workers in some species (Supporting Information, Table S2). In most species, only a proportion of colonies produce sexuals annually, and the number of males and young queens reared is usually limited (Pearcy \& Aron, 2006; Aron, Timmermans \& Pearcy, 2011; Jowers et al., 2013.

Table 1 summarizes data on thorax morphology in queens, mating behaviour, dispersal and mode of colony foundation. It includes published results, as well as unpublished field observations detailed in Supporting Information, Table S1.

\section{MATING BEHAVIOUR}

Emery (1925) and Santschi (1929) already recognized that female calling is typical of various species of Cataglyphis. Queens have been observed to mate close to their natal nest with a single or, more frequently, with multiple males, after which they usually disperse. Genetic data confirmed that queens mate multiply in most species (Aron et al., 2016a, b).

Reliable field observations on mating behaviour are available for 10 out of 18 Cataglyphis species. Males and young queens exit from natal nests over several days. Female calling occurs in all six species-groups, that is, C. tartessica (formerly C. floricola; Amor \& Ortega, 2014), C. sabulosa (Kugler, 1981), C. bombycina (Roger, 1859), C. velox (Santschi, 1929), C. livida (André, 1881), C. iberica (Emery, 1906), C. viatica (Fabricius, 1787), C. piliscapa and in one of the two populations of C. savignyi surveyed. Although mating was not directly observed in C. hispanica (Emery, 1906), C. mauritanica (Emery, 1906) and C. cretica (Forel, 1910), female calling is beyond doubt for two reasons: (1) queens lack wing muscles, hence cannot fly; (2) DCF occurs, implying that queens do not disperse away from natal nests before copulation. Mating behaviour remains undetermined for four species, that is, C. emmae (Forel, 1909), C. nigra, C. italica (Emery, 1906) and C. hellenica (Forel, 1886).

\section{COLONY FOUNDING}

Queen behaviours consistent with ICF have been reported in nine species (C. emmae, C. sabulosa, C. bombycina, C. livida, C. iberica (Emery, 1906), C. rosenhaueri (Santschi, 1925), C. viatica, C. savignyi and C. nigra). Queens were variously observed to land, break their wings, walk on the desert ground or dig holes in the ground. In line with this, microsatellite analyses revealed no evidence of IBD at a local spatial scale in four of these species (C. emmae, C. sabulosa, C. bombycina and C. livida) suggesting long-range dispersal by flight.

Conversely, colony fission (DCF) was observed in the field for C. tartessica, C. hispanica, C. velox, C. mauritanica and C. piliscapa. Mated queens left the natal nest on foot with nestmate workers, and/ or worker transports between two nests occurred at 
nuptial time. Genetic analyses are congruent with these observations; there is a significant positive correlation between geographic distance and genetic differentiation in C. hispanica, C. velox, C. mauritanica and $C$. piliscapa, consistent with DCF. In C. nigra, field observations from Israel (locality 1) and Iran suggest aerial dispersal followed by ICF, while genetic analyses from Israel (locality 2) indicate IBD, suggestive of dispersal by foot or by flight over short distances. However, genetic studies in Israel (locality 2) revealed that some populations evolved a unicolonial social structure, whereby queens disperse on foot over short distances, and individuals (queens, workers, brood) mix freely among physically separated nests (Leniaud et al., 2011; Saar et al., 2014) resulting in significant IBD. No field observations of colony founding behaviour are available for C. cretica, C. italica and C. hellenica (species-group cursor). Nonetheless, genetic analyses indicate IBD in these three species, which is congruent with either DCF or ICF preceded by queen dispersal over short distances by foot or by flight.

Non-claustral foundation has been reported in at least two species, C. iberica (Cerda \& Retana, 1991) and C. nigra (Fridman \& Avital, 1983; details in Supporting Information, Table S1). In both species, dealate mated queens (confirmed with spermatheca dissection) were observed foraging on the ground up to 1 month after the mating period. Non-claustral foundation is further supported by physiological data in C. iberica: queens show a much lower fat content relative to other ICF species (X. Cerda, pers. comm.).

Thus, ICF occurs in the four species-groups emmae, bombycinus, albicans and bicolor, possibly also in the group cursor, while DCF evolved in the three speciesgroups emmae, altisquamis and cursor.

\section{MORPHOLOGY OF QUEEN THORAX AND LACK OF FLIGHT ABILITY}

Queens of twelve species of Cataglyphis have a typical flight thorax characterized by a large mesonotum (Fig. 1a; also Wehner 1983) and normal wings. However, in six other species, we found that queens have short wings (when still attached) or their thorax segmentation (reduced mesonotum and large pronotum; Fig. 1b) deviate from that in flying queens. We checked for the presence of the large indirect wing muscles in 17 species (Table 1); in all brachypterous queens the thorax was partly empty or filled with white tissues (probably fat) that are visually distinct from long and thick wing fibres (Fig. 2). Whenever histolysis of wing muscles might have begun (i.e. slightly older queens, sometimes already dealate), we confirmed that the posterior phragma was absent. All species lacking wing muscles had a much smaller mesonotum. In C. italica and $C$. hellenica, queens have the machinery to fly but it is unclear if they disperse by foot (DCF) or by flight (ICF) over short distances.

\section{DISCUSSION}

Our comparative study of 18 species of Cataglyphis combines field observations, functional morphology and genetic data, to show a marked deviation from the breeding behaviour typical of many genera in subfamily Formicinae. In the majority of ants (including Formicinae), the annual period of sexual activity takes the form of short-lived 'male aggregations' where flying sexuals from many colonies meet and mate, after which queens attempt to found new colonies alone (ICF). Such male aggregations are rare in Cataglyphis. Instead, the young queens in most species wait for foreign males close to their natal nests. The lack of a pre-mating flight reduces mortality since queens benefit from the protection of nestmate workers and can quickly retreat inside the nest in case of a threat. Female calling also reduces the total time spent flying, hence a reduced exposition to the risks inherent to aerial dispersal. Nonetheless, risks are incurred during the post-mating flight, while queens search for suitable nesting sites. Our review indicates that aerial dispersal by queens was completely lost in various species from three out of the six species-groups studied: gr. emmae, gr. altisquamis and gr. cursor (Table 1). Once mated, such queens disperse on foot before attempting ICF, or they re-enter the natal nests and disperse later in the company of nestmate workers (DCF). Remarkably, at least six DCF species evolved non-flying brachypterous queens; in C. tartessica, ergatoid queens occur in addition to brachypterous queens (Amor et al., 2011). Thus, Cataglyphis queens show two degrees of reduction of aerial dispersal: loss of pre-mating flight in most species, and permanent loss of flying ability in a minority of species. In the absence of a more detailed molecular phylogeny including all species-groups in the genus, we cannot deduce what behaviours are basal, nor can we infer transitions between species-groups.

\section{REDUCTION IN FEMALE DISPERSAL: FEMALE CALLING}

Male aggregation predominates in the formicoid clade, which contains 10 of the 17 ant subfamilies and represents about $90 \%$ of all known ant species (Ward, 2014). Species with large colony size are usually able to produce enough sexuals to swamp predators and to compensate for the high rate of mortality associated with ICF ( $<1 \%$ of young queens survive; Bourke \& Franks, 1995). In contrast, female calling typically occurs in 
species with small colonies that produce relatively few female sexuals annually (Peeters \& Ito, 2001). Such species have widely dispersed colonies and too few sexuals occur synchronously for male aggregation to be viable. The lack of a pre-mating flight is typical of almost all poneroids, but it is scattered among the formicoid clade. This mating syndrome requires males to locate young virgin queens in the vicinity of their natal colonies. Males have bigger eyes than queens (this is true in Cataglyphis and many other genera), and we take this as evidence that they search for nests while flying, using the above ground activity of workers and queens as visual cues. Once a nest has been located, males are attracted by the sexual pheromones released by young queens (Hölldobler \& Haskins, 1977). Our review shows that female calling is characteristic of the genus Cataglyphis, occurring across six speciesgroups; of the 18 species studied, male aggregation has been documented in C. rosenhaueri and one population of $C$. savignyi only. Female calling is consistent with small mature colony size in Cataglyphis (relative to other Formicinae), ranging from a few hundred individuals (e.g. gr. emmae) to a few thousands in some species (e.g. gr. altisquamis) (Supporting Information, Table S2). Colonies typically show restricted investment in sexuals: not all colonies produce sexuals annually and, when they do, they raise few males and/or new queens (Supporting Information, Table S2).

Importantly, female calling was reported in the two closest relatives of Cataglyphis, namely Rossomyrmex and Proformica (Ward, Blaimer \& Fisher, 2016). Rossomyrmex minuchae (Tinaut, 1981) is a slavemaker that parasitizes Proformica longiseta (Collingwood, 1978) (Fernandez-Escudero, Seppä \& Pamilo, 2001; Ruano \& Tinaut, 2005; Tinaut et al., 2010). In $R$. minuchae, virgin queens 'call' near the natal nest, mate, then re-enter their nest. On the same day, the mated queens exit their nest and fly in search of a non-parasitized $P$. longiseta nest. Similarly, field observations and genetic analyses in $P$. longiseta suggest that emerging queens leave their nests, mate, then return to the natal nest and begin to reproduce. DCF occurs later. Both these species are characterized by small colony sizes (R. minuchae: $64-235$ workers/ colony; P. longiseta: 387-2252 workers/colony), and production of few sexuals. Polyergus also belongs to the same clade and shows female calling (Trager, 2013). Nonetheless, closely related Formica exhibit male aggregation (Sundström et al., 2005).

\section{REDUCTION IN FEMALE DISPERSAL: NON-FLYING QUEENS}

Although the vast majority of ants are wingless (i.e. workers), the flying ability of queens is critical for ecological dominance, allowing long-range dispersal and settlement of new habitats. Generally, insect flight is costly for reasons both physiological (wing muscles require energy for manufacture and cellular metabolism) (Marden, 2000) and ecological (risks due to predation or desiccation are proportional to duration of time in the air) (Clobert et al., 2002) Queens disperse by flight in the majority of ants, but this ability was lost in a few dozens of unrelated lineages, presumably because the cost of flight exceeds its benefits (Peeters, 2012).

Our data show that reduction of female dispersal in Cataglyphis culminates in the evolution of nonflying queens (Table 1). Six species have short-winged queens, and dissection of their thorax confirmed the lack of indirect wing muscles, both longitudinal and dorso-ventral (Fig. 2). This was reflected externally by a modified thorax morphology, particularly reduction of the mesonotum (Fig. 1b). Generally in ants, winglessness in workers corresponds to a highly simplified thorax (fusion of sclerites and reduced total volume) with a prominent pronotum and a reduced mesonotum (Keller et al., 2014). Similarly, queens lacking wing muscles have a modified thorax. Flightless queens have been reported in over 50 ant genera, but they usually take the form of ergatoid queens with a thorax very similar to that of workers (Peeters, 2012). In contrast, brachypterous queens retain non-functional short wings as well as distinct flight sclerites, that is, not fused as in ergatoid queens (Tinaut \& Ruano, 1992; Peeters et al., 2012). Brachypterous queens quickly break their short wings, but the remaining wing bases are misleading as they suggest flight ability. As a result, the occurrence of brachypterous queens is probably underestimated in ants. In Cataglyphis, the lack of wing muscles was first described (by histology) in C. tartessica (Amor et al., 2011). We extend this finding to another five species belonging to different lineages. Moreover, our results confirm the significance of brachypterous queens as fully functional reproductives that disperse on foot. Their abdomen is larger than that of workers (Supporting Information Figure S2), and they have more ovarioles (CP, unpublished). In C. nigra (Israel 2), C. italica and C. hellenica, young queens have normal wings and wing muscles indicating that they are capable of flying. However, population genetic data reveal a strong IBD pattern consistent with very short distance dispersal. This suggests a dispersal polymorphism that is independent of the morphology of individuals. Queens either disperse or not, and this may be influenced by habitat structure and stability, kin competition or other biotic and abiotic factors.

All Cataglyphis species that show DCF have nonflying queens. Brachypterous and ergatoid queens are less costly to produce given the lack of wing muscles. Moreover, the shift from ICF (C. emmae) to DCF (C. tartessica) is associated with reduction of thorax size (i.e. 
winged queens have a bigger thorax than brachypterous queens; Amor et al., 2011). Similarly, in the ant genera Rhytidoponera and Mystrium, winged queens are replaced by smaller reproductives (gamergates and ergatoid queens, respectively; Molet, Van Baalen \& Peeters, 2008; Molet et al., 2009). In C. bombycina, queens are dimorphic in size, with both microgynes and macrogynes (Molet, Maicher \& Peeters, 2014). The function of microgynes is currently unknown. Since they are less costly to produce relative to macrogynes, more of them can be reared with the same amount of resources. Having microgynes in addition to macrogynes seems advantageous for colonies. In other ant genera (e.g. Rüppell \& Heinze, 1999), macrogynes typically perform ICF, that is, they fly away from their natal nest, mate, and found alone, while microgynes stay in their natal nest, mate and participate in DCF.

\section{DCF VERSUS ICF}

Dispersal by foot and DCF occur in the three species-groups emmae, altisquamis and cursor (Table 1 and Supporting Information Table S1). The topology of the phylogenetic tree for Cataglyphis (Aron et al., $2016 \mathrm{~b})$ suggests three independent shifts from ICF to DCF. Ecological factors such as habitat patchiness, nest site limitation, competition, predation, climate, resource availability and nest site instability (Cronin et al., 2013) are likely to play a key role in this shift. Although all Cataglyphis species are thermophilous, they inhabit substantially diverse habitats, from harsh sand dunes in the Sahara, to more hospitable coastal sand dunes, to mountains resembling arid steppes (partially covered by snow in winter, while summer is very hot, sunny and dry). Mountainous and coastal sites have more vegetation, hence more nesting sites and better food availability. We suggest that in species occupying extreme arid habitats (C. bombycina, C. sabulosa, C. viatica, C. savignyi), flight is essential for mated queens to discover suitable nesting sites, for example, small clumps of grass or shrubs. Indeed, sand-nesting species require roots as scaffolding for their nest chambers, together with the associated moisture (Délye, 1968: 108-115). DCF is unsuccessful in such habitats because scouts (i.e. older experienced workers) cannot easily locate new nesting sites that are few and far between, prior to queens and nestmate workers dispersing on foot. In contrast, in Cataglyphis species inhabiting milder habitats with more ground vegetation (C. tartessica, C. velox, C. mauritanica, C. hispanica, as well as all species of the cursor group), DCF is viable because nesting sites are less scarce. More nesting sites also means weaker competition among foundresses. Data on colony density are scarce in Cataglyphis, but field observations (SA, pers. comm.) suggest that in harsh habitats, colonies show lower density (e.g. C. bombycina, C. sabulosa). In contrast, the density of colonies is higher in more favourable environments (e.g. C. piliscapa, C. mauritanica). Moreover, Peeters (1997) postulated that the shift from ICF to DCF is caused by limited resources, when colonies cannot produce sufficient sexuals to compensate the high mortality linked with ICF. Consistent with this hypothesis, Cataglyphis typically have small colonies with a limited foraging force, and this likely limits the number of sexuals produced.

Another, non-exclusive explanation for the shift to DCF in Cataglyphis focuses on the production of queens by asexual reproduction. In four of the five DCF species (C. hispanica, C. velox, C. mauritanica, C. piliscapa), new queens are commonly produced asexually by thelytokous parthenogenesis with central fusion of polar nuclei (Aron et al., 2016b; Boulay et al., 2017). This is also the case in the three species C. cretica, C. italica and C. hellenica (A. Kuhn, unpubl. data) where genetic data reveal a strong pattern of IBD characteristic of DCF. By increasing levels of homozygosity, this mode of parthenogenesis can result in reduced queen survival and fitness, much like inbreeding does (Pearcy et al., 2004). Selection against young founding queens should be strong because they are alone to face environmental pressures. Thus, selection against homozygous queens should be lower in DCF species because they benefit from the help and protection of a genetically diverse worker force arising from classical sexual reproduction (Pearcy et al., 2004). In line with this hypothesis, the association between DCF and parthenogenetic production of queens has been documented in other ants, including Wasmannia auropuncata (Roger, 1863) (Fournier et al., 2005), Vollenhovia emeryi (Wheeler, 1906) (Ohkawara et al., 2006) and Paratrechina longicornis (Latreille, 1802) (Pearcy, Goodisman \& Keller, 2011), as well as several termites (reviewed in Fournier et al., 2016).

Ant genera with flightless queens (brachypterous or ergatoid) generally show DCF, but ICF was reported in Myrmecia, Plectroctena and Pogonomyrmex (Johnson, 2002; Peeters et al., 2012). More species of Cataglyphis need to be studied to determine if brachyptery can occur together with ICF. Because there is a high probability that species with flightless queens will go extinct over evolutionary time (Peeters, 2012), flying queens are likely to predominate in Cataglyphis, especially in Arabian deserts that are relatively unstable and patchy habitats (Boulay et al., 2017).

\section{POPULATION STRUCTURE AND ASYMMETRIC DISPERSAL OF SEXES}

As expected, genetic analyses indicated a strong pattern of IBD in species where queens disperse by foot (Table 1; C. hispanica, C. velox, C. mauritanica, 
C. piliscapa and C. cretica all have brachypterous queens). Dispersal remains somewhat ambiguous in a few other species. In C. nigra, field observations of dispersal by flight, dealate queens running alone and digging holes in the soil at nuptial time are consistent with ICF. However, detailed genetic analyses show high population viscosity indicative of either DCF or ICF by foot or by flight over short distances. Such apparent disparity may have two explanations. First, field observations and genetic analyses were done on C. nigra populations from different localities (Iran and Israel) and by different researchers (Table 1), thus distinct species may be involved (C. nigra belongs to the bicolor group where species delimitation is problematic). Second, C. nigra may show plasticity in dispersal strategy and mode of colony foundation. Indeed, substantial differences in social structure between populations have been reported, indicating that in certain sites the population is polydomous and multicolonial while in other sites it is unicolonial (Leniaud et al., 2011; Saar et al., 2014). IBD may therefore result from unicoloniality (neighbouring colonies exchange workers and are consequently genetically more similar than distant colonies) rather than from queen dispersal over short distances. Another possibility is that post-mating flights are very short, hence mated queens remain in the vicinity of their natal nest. In C. italica and C. hellenica, thorax dissections indicate normal wing muscles, yet population genetics show strong IBD (A. Kuhn, unpubl. data), suggesting mated queens fly very little or not at all.

Dispersal distances of young queens are available for three Cataglyphis species with DCF (reviewed in Boulay et al., 2017). In C. piliscapa, dispersal ranges from 1 to $30 \mathrm{~m}$, with an average of 7-8 m (Lenoir et al., 1988; Chéron et al., 2011). Similar values were reported for C. tartessica (Amor, 2011; Amor et al., 2011) and C. mauritanica (Knaden \& Wehner 2006). In C. piliscapa, population genetics (nuclear and mitochondrial DNA) indicated large differences in dispersal distances between the sexes (Clémencet, Viginier \& Doums, 2005). At a fine spatial scale (less than a few kilometres), the level of genetic differentiation for mitochondrial markers was 15 times higher than for nuclear markers. Thus, males disperse significantly further than females. Such sex-biased gene flow may explain why mating pairs are on average unrelated and inbreeding coefficient is (usually) not different from zero. Although males are the dispersing sex in C. piliscapa, both theoretical and experimental studies show that dispersal distances do not exceed a few tens or hundreds of metres, resulting in high genetic differentiation even within populations at relatively small spatial scales (Clémencet et al., 2005; Hardy, Pearcy $\&$ Aron, 2008). This sets the stage for phenotypic and genetic differentiation among populations, leading to increased opportunities for allopatric or parapatric divergence within a given area. The recent speciation (< $1 \mathrm{Myr}$ ) between C. floricola and C. tartessica, two species living in parapatry across continuous sandy habitat in southern Spain, lends credence to this hypothesis (Jowers et al., 2014).

\section{LOSS OF CLAUSTRAL BEHAVIOUR DURING ICF}

Inseminated queens of $C$. nigra have been observed to forage repeatedly and retrieve prey to newly excavated nests (Fridman \& Avital, 1983), which is convincing evidence for non-claustral colony foundation. Likewise, queen foraging was observed in C. iberica (Cerda \& Retana, 1991). In both these species (bicolor and albicans species-groups, respectively), queens disperse by flight and found their colony independently. It is currently unknown if non-claustral ICF occurs in other species of Cataglyphis.

Non-claustral foundation is ancestral in ants (Keller et al., 2014). It is universal in subfamilies Amblyoponinae, Ponerinae (one exception: Brachyponera lutea), Ectatomminae and Myrmeciinae, whereas claustral species are strictly restricted to subfamilies Dolichoderinae, Formicinae and Myrmicinae (Peeters \& Ito, 2015). Non-claustral foundation is associated with high queen mortality due to risks of predation or becoming lost (Peeters, 1997). In contrast, claustral queens accumulate metabolic reserves that make it unnecessary to go outside the nest. Enlarged wing muscles are required to carry bigger protein and fat reserves during flight (Helms \& Kaspari, 2015), and these muscles are later broken down and resulting amino acids fed to the first larvae. Importantly, reversal to non-claustral ICF has been documented in at least 12 genera of Myrmicinae and two genera of Formicinae, a total of 28 species (reviewed in Brown \& Bonhoeffer, 2003; Hahn et al., 2004; Keller et al., 2014). The secondary evolution of non-claustrality may be an adaptive response to local ecological conditions, for example, plentiful and predictable food (Peeters \& Molet, 2010). This is indeed the case in C. nigra and C. iberica, which inhabit arid locations with higher plant cover.

Our review shows an overall reduction in female dispersal in Cataglyphis ants. Queens mate close to natal nests in a majority of species, and queens evolved irreversible loss of flight in a minority of these species. To date, information on dispersal and colony founding are available for less than a fifth of known species (18/91) of Cataglyphis. Non-flying queens with abnormally short wings may occur in other species and, once dealate, can be recognized by their modified thorax (Fig. 1b). Similarly, mating and founding behaviours 
remain unstudied in most ant genera, and it is commonly assumed that presence of wings is equivalent to aerial dispersal. Our integration of functional morphology and population genetic data can shed light on the crucial moment when queens exist as individuals.

\section{ACKNOWLEDGEMENTS}

We thank R. Boulay, H. Darras, C. Doums and T. Monnin for their critical comments on an earlier version of this manuscript. F. Amor, P. Seppa and R. Wehner provided constructive referee reports. F. Amor, H. Darras, P.A. Eyer, A. Kuhn, T. Monnin and A. Tinaut provided specimens of queens from various species. R. Boulay, X. Cerdà, P. Hönle and R. Wehner shared their field observations of mating behaviour. A. Khalife created all stacked images of queen thorax and wing muscles. This comparative study was conceived during CP's stay as Invited Professor at ULB. Our work was supported by Wallonie-Bruxelles International and the Fonds de la Recherche Scientifique (FRS-FNRS) (Belgium), as well as the French Ministry of Foreign and European Affairs and Ministry of Higher Education and Research (Tournesol/Hubert Curien Partnerships; grant \# 2016/272.300).

\section{REFERENCES}

Agosti D. 1990. Review and reclassification of Cataglyphis (Hymenoptera Formicidae). Journal of Natural History 24: 1457-1506.

Amor F. 2011. Social structure, resource exploitation and distribution of the ant Cataglyphis floricola Tinaut 1993. Unpublished D. Phil. Thesis, University of Sevilla.

Amor F, Ortega P. 2014. Cataglyphis tartessica sp. n., a new ant species (Hymenoptera: Formicidae) in south-western Spain. Myrmecological News 19: 125-132.

Amor F, Ortega P, Jowers MJ, Cerdá X, Billen J, Lenoir A, Boulay RR. 2011. The evolution of worker-queen polymorphism in Cataglyphis ants: interplay between individual and colony-level selections. Behavioral Ecology and Sociobiology 65: $1473-1482$.

Aron S, Darras H, Eyer PA, Leniaud L, Pearcy M. 2013. Structure génétique des sociétés et systèmes d'accouplement chez la fourmi Cataglyphis viatica (Fabricius 1787). Bulletin de l'Institut Scientifique de Rabat 35: 103-109.

Aron S, Lybaert P, Baudoux C, Vandervelden M, Fournier D. 2016a. Sperm production characteristics vary with level of sperm competition in Cataglyphis desert ants. Functional Ecology 30: 614-624.

Aron S, Mardulyn P, Leniaud L. 2016b. Evolution of reproductive traits in Cataglyphis desert ants: mating frequency, queen number, and thelytoky. Behavioral Ecology and Sociobiology 70: 1367-1379.
Aron S, Timmermans I, Pearcy M. 2011. Ant queens adjust egg fertilization to benefit from both sexual and asexual reproduction. Biology Letters 7: 571-573.

Boulay R, Aron S, Cerda X, Doums C, Graham P, Hefetz A, Monnin T. 2017. Social life in arid environments: the case study of Cataglyphis ants Annual Review of Entomology 62: 305-321.

Bourke A, Franks N. 1995. Social evolution in ants. Princeton: Princeton University Press.

Brown MJF, Bonhoeffer S. 2003. On the evolution of claustral colony founding in ants. Evolutionary Ecology Research 5: 305-313.

Cerda X, Retana J. 1991. Sobre la fundacion de la sociedad en la hormiga Cataglyphis iberica (Emery, 1906) (Hymenoptera: Formicidae). Orsis 6: 127-139.

Chéron B, Cronin AL, Doums C, Fédérici P, Haussy C, Tirard C, Monnin T. 2011. Unequal resource allocation among colonies produced by fission in the ant Cataglyphis cursor. Ecology 92: 1448-1458.

Clémencet J, Viginier B, Doums C. 2005. Hierarchical analysis of population genetic structure in the monogynous ant Cataglyphis cursor using microsatellite and mitochondrial DNA markers. Molecular Ecology 14: 3735-3744.

Clobert J, Danchin E, Dhondt A, Nichols J. 2002. Dispersal ecology. Malden: Blackwell.

Cronin AL, Fédérici P, Doums C, Monnin T. 2012. The influence of intraspecific competition on resource allocation during dependent colony foundation in a social insect. Oecologia 168: 361-369.

Cronin AL, Molet M, Doums C, Monnin T, Peeters C. 2013. Recurrent evolution of dependent colony foundation across eusocial insects. Annual Review of Entomology 58: 37-55.

Darras H, Leniaud L, Aron S. 2014. Large-scale distribution of hybridogenetic lineages in a Spanish desert ant. Proceedings of the Royal Society of London B 281: 20132396.

Délye G. 1968. Recherches sur l'écologie, la physiologie et l'éthologie des fourmis du Sahara. D. Phil. Thesis, Université d'Aix Marseille.

Emery C. 1925. Genus Cataglyphis, Förster. In: Wystman P, ed. Genera Insectorum. Familia Formicidae, subfamilia Formicinae. Bruxelles, 261-267.

Eyer PA, Leniaud L, Tinaut A, Aron S. 2016. Combined hybridization and mitochondrial capture shape complex phylogeographic patterns in hybridogenetic Cataglyphis desert ants. Molecular Phylogenetics and Evolution 105: 251-262.

Fernández-Escudero I, Seppä P, Pamilo P. 2001. Dependent colony founding in the ant Proformica longiseta. Insectes Sociaux 48: 80-82.

Fournier D, Estoup A, Orivel J, Foucaud J, Jourdan H, Le Breton J, Keller L. 2005. Clonal reproduction by males and females in the little fire ant. Nature $\mathbf{4 3 5}$ : $1230-1234$.

Fournier D, Hellemans S, Hanus R, Roisin Y. 2016. Facultative asexual reproduction and genetic diversity of populations in the humivorous termite Cavitermes tuberosus. Proceedings of the Royal Society of London B 283: 20160196.

Fridman S, Avital E. 1983. Foraging by queens of Cataglyphis bicolor nigra (Hymenoptera: Formicidae): an 
unusual phenomenon among the Formicinae. Israel Journal of Zoology 32: 229-230.

Hahn DA, Johnson RA, Buck NA, Wheeler DE. 2004. Storage protein content as a functional marker for colony-founding strategies: a comparative study within the harvester ant genus Pogonomyrmex. Physiological and Biochemical Zoology: PBZ 77: 100-108.

Hardy O, Pearcy M, Aron S. 2008. Small-scale spatial genetic structure in an ant species with sex-biased dispersal. Biological Journal of the Linnean Society 93: 465-473.

Helms JA, Kaspari M. 2015. Reproduction-dispersal tradeoffs in ant queens. Insectes Sociaux 62: 171-181.

Hölldobler B, Haskins CP. 1977. Sexual calling behavior in primitive ants. Science 195: 793-794.

Johnson RA. 2002. Semi-claustral colony founding in the seed-harvester ant Pogonomyrmex californicus: a comparative analysis of colony founding strategies. Oecologia 132: 60-67.

Jowers MJ, Amor F, Ortega P, Lenoir A, Boulay RR, Cerda X, Galarza JA. 2014. Recent speciation and secondary contact in endemic ants. Molecular Ecology 23: 2529-2542.

Jowers MJ, Leniaud L, Cerdá X, Alasaad S, Caut S, Amor F, Aron S, Boulay R. 2013. Social and population structure in the ant Cataglyphis emmae. PLoS ONE 8: e72941.

Keller RA, Peeters C, Beldade P. 2014. Evolution of thorax architecture in ant castes highlights trade-off between flight and ground behaviors. eLife 3: e01539.

Knaden M, Tinaut A, Stokl J, Cerda X, Wehner R. 2012. Molecular phylogeny of the desert ant genus Cataglyphis (Hymenoptera: Formicidae). Myrmecological News 16: 123-132.

Knaden M, Wehner R. 2006. Fundamental difference in life history traits of two species of Cataglyphis ants. Frontiers in Zoology 3: 21.

Leniaud L, Darras H, Boulay R, Aron S. 2012. Social hybridogenesis in the clonal ant Cataglyphis hispanica. Current Biology: CB 22: 1188-1193.

Leniaud L, Hefetz A, Grumiau L, Aron S. 2011. Multiple mating and supercoloniality in Cataglyphis desert ants. Biological Journal of the Linnean Society 104: 866-876.

Leniaud L, Pearcy M, Aron S. 2013. Sociogenetic organisation of two desert ants. Insectes Sociaux 60: 337-344.

Lenoir A, Aron S, Cerda X, Hefetz A. 2009. Cataglyphis desert ants: a good model for evolutionary biology in Darwin's anniversary year - a review. In memoriam J. Kugler (19162007). Israel Journal of Zoology 39: 1-32.

Lenoir A, Quérard L, Pondicq N, Berton F. 1988. Reproduction and dispersal in the ant Cataglyphis cursor (Hymenoptera, Formicidae). Psyche 95: 21-44.

Marden JH. 2000. Variability in the size, composition, and function of insect flight muscles. Annual Review of Physiology 62: 157-178.

Molet M, Fisher B, Ito F, Peeters C. 2009. Shift from independent to dependent colony foundation and evolution of 'multi-purpose' ergatoid queens in Mystrium ants (subfamily Amblyoponinae). Biological Journal of the Linnean Society 98: 198-207.
Molet M, Maicher V, Peeters C. 2014. Bigger helpers in the ant Cataglyphis bombycina: increased worker polymorphism or novel soldier caste? PLoS ONE 9: e84929.

Molet M, Van Baalen M, Peeters C. 2008. Shift in colonial reproductive strategy associated with a tropical-temperate gradient in Rhytidoponera ants. The American Naturalist 172: $75-87$.

Ohkawara K, Nakayama M, Satoh A, Trindl A, Heinze J. 2006. Clonal reproduction and genetic caste differences in a queen-polymorphic ant, Vollenhovia emeryi. Biology Letters 2: 359-363.

Pearcy M, Aron S. 2006. Local resource competition and sex ratio in the ant Cataglyphis cursor. Behavioral Ecology 17: 569-574.

Pearcy M, Aron S, Doums C, Keller L. 2004. Conditional use of sex and parthenogenesis for worker and queen production in ants. Science 306: 1780-1783.

Pearcy M, Goodisman MAD, Keller L. 2011. Sib mating without inbreeding in the longhorn crazy ant. Proceedings of the Royal Society of London B 278: 2677-2681.

Peeters C. 1997. Morphologically "primitive" ants: comparative review of social characters, and the importance of queenworker dimorphism. In: Choe J, Crespi B, eds. The evolution of social behavior in insects and arachnids. Cambridge: Cambridge University Press, 372-391.

Peeters C. 2012. Convergent evolution of wingless reproductives across all subfamilies of ants, and sporadic loss of winged queens (Hymenoptera: Formicidae). Myrmecological News 16: 75-91.

Peeters C, Ito F. 2001. Colony dispersal and the evolution of queen morphology in social Hymenoptera. Annual Review of Entomology 46: 601-630.

Peeters C, Ito F. 2015. Wingless and dwarf workers underlie the ecological success of ants (Hymenoptera: Formicidae). Myrmecological News 21: 117-130.

Peeters C, Keller RA, Johnson RA. 2012. Selection against aerial dispersal in ants: two non-flying queen phenotypes in Pogonomyrmex laticeps. PLoS ONE 7: e47727.

Peeters C, Molet M. 2010. Colonial reproduction and life histories. In: Lach L, Parr C, Abbott K, eds. Ant ecology. Oxford: Oxford University Press, 159-176.

Radchenko AG. 2001. The phylogeny and faunogenesis of the genus Cataglyphis Foerster (Hymenoptera, Formicidae). Entomological Review 81: 951-958.

Ross KG. 2001. Molecular ecology of social behaviour: analyses of breeding systems and genetic structure. Molecular Ecology 10: 265-284.

Rousset F. 2000. Genetic differentiation between individuals. Journal of Evolutionary Biology 13: 58-62.

Ruano F, Tinaut A. 2005. Mating behaviour in a slave-making ant, Rossomyrmex minuchae (Hymenoptera, Formicidae). Die Naturwissenschaften 92: 328-331.

Rüppell O, Heinze J. 1999. Alternative reproductive tactics in females: the case of size polymorphism in winged ant queens. Insectes Sociaux 46: 6-17.

Saar M, Leniaud L, Aron S, Hefetz A. 2014. At the brink of supercoloniality: genetic, behavioral and 
chemical assessments of population structure of the desert ant Cataglyphis niger. Frontiers in Ecology and Evolution 2: $1-10$.

Santschi F. 1929. Etude sur les Cataglyphis. Revue Suisse de Zoologie 36: 25-70.

Shalmon B. 1981. A preliminary note on the biology of Cataglyphis sabulosa Kugler (Hymenoptera: Formicidae) in the southern Arava valley, Israel. Israel Journal of Zoology 15: 103.

Slatkin M. 1993. Isolation by distance in equilibrium and nonequilibrium populations. Evolution 47: 264-279.

Snodgrass RE. 1956. Anatomy of the honey bee. New York: Cornell University Press.

Sundström L, Seppä P, Pamilo P. 2005. Genetic population structure and dispersal patterns in Formica ants - a review. Annales Zoologici Fennici 42: 163-177.

Timmermans I, Grumiau L, Hefetz A, Aron S. 2010. Mating system and population structure in the desert ant Cataglyphis livida. Insectes Sociaux 37: 39-46.

Tinaut A, Ruano F. 1992. Braquipterismo y apterismo en formicidos. Morfologia y biometria en las hembras de especies ibericas de vida libre (Hymenoptera: Formicidae). Graellsia 48: 121-131.
Tinaut A, Ruano F, Sanllorente O, FernandezZambrano A, Karaman C, Kaz Y. 2010. Nest composition and worker relatedness in three slave-making ants of the genus Rossomyrmex Arnoldi and their Proformica Ruzsky hosts (Hymenoptera, Formicidae). Insect Science 17: 361-368.

Trager JC. 2013. Global revision of the dulotic ant genus Polyergus (Hymenoptera: Formicidae, Formicinae, Formicini). Zootaxa 3722: 501-548.

Vitikainen EI, Haag-Liautard C, Sundström L. 2015. Natal dispersal, mating patterns, and inbreeding in the ant Formica exsecta. The American Naturalist 186: 716-727.

Ward PS. 2014. The phylogeny and evolution of ants. Annual Review of Ecology and Systematics 45: 23-43.

Ward PS, Blaimer BB, Fisher BL. 2016. A revised phylogenetic classification of the ant subfamily Formicinae (Hymenoptera: Formicidae), with resurrection of the genera Colobopsis and Dinomyrmex. Zootaxa 4072: 343-357.

Wehner R. 1983. Taxonomie, Funktionsmorphologie und Zoogeographie der saharischen Wüstenameise Cataglyphis fortis (Forel 1902) stat. nov. (Insecta: Hymenoptera: Formicidae). Senckenbergiana Biologica 64: 89-132.

Wilson EO. 1971. The insect societies. Harvard: Belknap Press.

\section{SUPPORTING INFORMATION}

Additional Supporting Information may be found in the online version of this article at the publisher's web-site:

Table S1. Field observations of mating, dispersal and founding behaviour in Cataglyphis desert ants.

Table S2. Mature colony size and sexual production in different Cataglyphis species.

Figure S1. Presence or absence of wing muscles inside Cataglyphis queen thorax.

Figure S2. Weak dimorphism in body size and thorax structure between workers and brachypterous queen in Cataglyphis velox.

Figure S3. Thorax structure of flying queen in Cataglyphis fortis. From Wehner (1983). 